\title{
Meningkatkan Minat Belajar Siswa Dengan Menggunakan Metode Dikusi Pada Mata Pelajaran Akidak Akhlak Kelas VII Mts NW Suralaga
}

\author{
Muhammad Yamin \\ yaminflores826@gmail.com \\ Manajemen Pendidikan Islam, STAI Darul Kamal NW Kembang Kerang, Indonesia
}

\begin{abstract}
Abstrak
Pelaksanaan proses pembelajaran dalam penelitian ini menggunakan metode diskusi. Penelitian ini bertujuan untuk meningkatkan minat belajar pada mata pelajaran Akidah Akhlak. Bentuk penelitian ini adalah penelitian tindakan kelas (PTK). Subyek dalam penelitian ini adalah siswa kelas VII MTs NW Suralaga. Semester 1 tahun pelajaran 2021/2O22. Adapun jumlah siswa kelas VII sebanyak 18 orang siswa (10 putra, 8 putri). Data dikumpulkan melalui observasi, dokumentasi, dan wawancara. Analisis data yang digunakan dalam penelitian ini yaitu analisis data kualitatif diperoleh dari hasil observasi terhadap minat belajar siswa dan kegiatan guru selama proses kegiatan pembelajaran. Hasil penelitian ini menunjukkan adanya peningkatan minat belajar Akidah Akhlak dari pada siklus I hasil evaluasi mengenai peningkatan minat belajar siswa masih sedikit yang meningkat, siklus II Hasil evaluasi mengenai peningkatan minat belajar siswa sudah mulai meningkat dan siklus III siswa sudah aktif dan tidak malu-malu lagi untuk bertanya. Untuk mengetahui minat siswa melalui metode diskusi digunakan indikator minat belajar siswa sebagai pedoman guru antara lain Senang terhadap mata pelajaran Akidah Akhlak, memperhatikan apa yang disampaikan guru, aktif dalam kegiatan pembelajaran Akidah Akhlak dan Ketertarikan terhadap mata pelajaran Akidah Akhlak. Kesimpulan penelitian ini adalah metode diskusi dapat meningkatkan minat belajar siswa.
\end{abstract}

Kata kunci : minat belajar siswa, metode diskusi

\section{Pendahuluan}

Meningkatkan kutalitas sumber daya manusia merupakan syarat mutlak untuk mencapai tujuan pembangunan. Salah satu cara untuk meningkatkan kualitas sumber daya manusia tersebut adalah pendidikan. Undang-undang Republik Indonesia NO. 20 Tahun 2003 tentang sistem pendidikan nasional Bab 1 pasal 1 menegaskan bahwa

"Pendidikan adalah usaha sadar dan terencana untuk mewujudkan belajar dan proses pembelajaran agar peserta didik secara aktif mengembangkan potensi dirinya untuk memiliki kekuatan spritual keagamaan, pengendalian diri, kepribadian, kecerdasan, akhlak mulia, serta keterampilan yang diperlukan dirinya, masyarakat, bangsa, dan agama." 
Untuk mencapai tujuan pendidikan tersebut seorang pendidik selalu memilih metode pengajaran yang tepat dan efektif. Makin tepat metodenya, diharapakan makin aktif pula pencapaian tujuan tersebut. Dalam preses pembelajaran tidak hanya guru yang selau menyampaikan materi, tetapi guru pun hendaknya memberikan kesempatan kepada siswa untuk menyumbangkan pikiran dan pendapatnya terhadap persoalan yang dihadapi dalam preses pembelajaran.

Adapun pengertian metode menurut M. Sobry Sutikno, metode secara harfiyah berarti "cara". Dalam pemeakian umum, metode diartikan sebagai suatu cara atau prosedur yang dipakai untuk mencapai tujuan tertentu. Kata "pembelajaran" berarti segala upaya yang dilakukan oleh pendidik agar terjadi proses belajar pada diri sendiri.

Menggunakan metode yang monoton dalam pembelajaran akan menyebabkan siswa cepat jenuh sebab tidak ada variasi. Jadi metode adalah cara yang dalam fungsinya merupakan alat untuk mencapai tujuan, makin tepat metodenya diharapkan makin efektif pula tujuan tersebut. Metode yang digunakan guru harus disesuaikan dengan materi pelajaran yang akan disampaikan, karena metode merupakan alat untuk menciptakan proses pembelajaran seerta berpengaruh bagi keberhasilan siswa dalam belajar. Jika guru tidak pandai memilih dan menggunakan metode yang tepat dalam pembelajaran, siswa akan sulit pula dalam menerima dan memahami materi pelajaran yang disampaikan guru. Oleh karena itu, semakin tepat penerapan metode mengajar, maka akan tepat pula tujuan pengajarannya. Dalam kaitannya dengan penggunaan metode mengajar, metode diskusi salah satu metode yang tepat dalam menyajikan materi pelajaran, karena dengan metode diskusi suasana kelas menjadi hidup, merangsang siswa agar perhatiannya tercurah kepada masalah yang dibicarakan serta melatih siswa agar berani mengembangkan pendapat dengan lisan dan teratur.

Menurut Zuhairini, dkk, metode diskusi merupakan suatu metode didalam mempelajari bahan atau menyampaikan bahan dengan jalan mendidskusikannya, sehingga berakibat menimbulkan pengertian serta perubahan tingkah laku murid. Metode ini dimaksusdkan untuk merangsang murid berpikir dan mengeluarkan pendapat sendiri, serta ikut menyumbangkan pikiran dalam satu masalah bersama yang terkandung banyak kemungkinan. 
Dengan demikian, dalam proses pembalajaran guru harus memberikan kesempatan kepada siswa untuk dapat berpartisipasi secara aktif dalam forum diskusi. Semakin banyak siswa yang terlibat dan menyumbangkan pikirannya, semakin banyak pula yang dapat mereka pelajari. Sehingga dapat berpengaruh pada meningkatkan minat belajar siswa.

Meningkatkan minat belajar siswa adalah hasil yang telah dicapai dari dilakukan, dikerjakan, dan sebagainya. Sedangkan belajar adalah suatu proses yang ditandai dengan suatu perubahan pada diri seseorang. Meningkatkan minat belajar pada dasarnya mencerminkan sejauh mana konstribusi seorang guru dalam mendidik dan membina siswa dengan menggunakan metode diskusi. Sehingga meningkatkan minat belajar siswa semakin meningkat yang telah ditentukan bagi masing-masing mata pelajaran atau bidang studi, salah satunya dalam bidang studi Akidah Akhlak yang merupakan salah satu ruang lingkup dari pendidikan Agama Islam. Dalam proses pembelajaran, metode diskusi dapat memberikan kesempatan kepada siswa untuk kreatif dalam menampilkan tanya jawab, berkomentar, berpendapat, memberi saran dan kritik, menanggapi, menolak, dan menerima pendapat orang lain. Dengan menggunakan metode diskusi siswa diharapkan termotIvasi untuk aktif dalam proses pembalajaran, sehingga dapat meningkatkan minat belajar siswa.

Berdasarkan PTK yang dilaksanakan pada tanggal 11 Otober 2021 dikelas VII Madrasah Stanawiyah (MTs) NW Suralaga diproleh data bahwa dalam menyampaikan materi Akidah Akhlak guru telah berupaya seoptimal mungkin supaya siswa meningkatkan minat belajar lebih baik, seperti merangsang siswa untuk aktif dalam mengikuti kegiatan pembelajaran, dan pembagian kelompok dalam kelas. Dalam hal ini, guru telah menerapkan metode diskusi, dengan harapan dapat membantu kreatifitas siswa dalam memecahkan masalah dan meningkatkan minat belajar siswa kelas VII pada mata pelajaran Akidah Akhlak.

Namun ternyata, masih ada beberapa siswa yang pasif dalam proses pembelajaran menggunakan metode diskusi, karena dengan sikap kepasifannya dalam berdiskusi dapat mempengaruhi meningkatkan minat belajar. Berdasarkan hal tersebut, penulis mengangkat judul penelitian tindakan kelas (PTK) yaitu. “Meningkatkan Minat 
Belajar Siswa dengan Menggunakan Metode Diskusi pada Mata Pelajaran Akidah Akhlak di Kelas VII MTs NW Suralaga.

\section{Metode Penelitian}

Penelitian ini merupakan jenis penelitian tindakan kelas (PTK). Dengan subjek penelitian adalah siswa kelas VII berjumlah 18 orang. 10 orang siswa laki-laki dan 8 orang siswi perempuan di MTs NW Surlaga Kecamatan Suralaga kabupaten Lombok Timur. Waktu penelitian dilakukan pada tanggal 11 Oktober 2021 samapai 3 November 2021 tahun pelajaran 2021/2022. Penelitian dilaksanakan sebanya 3 siklus yang terdiri dari 4 fase kegiatan yaitu : perencanaan, pelaksanaan, observasi dan refleksi. Pada tahap perencanaan ini peneliti melakukan persiapan-persiapan antara lain: 1) Membuat rencana pelaksanaan pembelajaran (RPP) tentang materi yang akan diajarkan dengan menggunakan metode diskusi. Materi yang akan diajarkan pada siklus satu yaitu pengertian shalat dan pengertian dzikir. 2) Membuat instrumen untuk mengetauhi minat belajar siswa pada siklus 1. Pada fase pelaksanaan, peneliti melakukan langkahlangkah berikut:

1) Peneliti menyampaikan tujuan pembelajaran dan kegiatan yang akan dilaksanakan.

2) Peneliti memberikan apersepsi tentang materi yang akan diajarkan.

3) Peneliti membagi siswa menjadi 3 kelompok yang terdiri dari 6 siswa.

4) Peneliti memberikan kesempatan kepada setiap kelompok untuk mendiskusikan materi yang diberikannya kemudian mempresentasikan hasil kerja kelompoknya.

5) Setiap kelompok diberikan kesempatan untuk bertanya.

6) Peneliti memberikan bimbingan kepada siswa selama berjalannya diskusi.

7) Mengevaluasi proses dan hasil diskusi.

Selanjutnya pada fase Observasi, peneliti mengamati keaktifan siswa pada saat kegiatan pembelajaran berlangsung. Adapun yang perlu diamati adalah aktivitas siswa konsentrasi siswa yang aktif bertanya dan siswa yang bisa menjawab pertanyaan dari guru maupun sesama siswa. Fase terakhir refleksi, dilakukan untuk menentukan apakah siklus tersebut harus diulangi atau sudah berhasil. 
Data dalam penelitian ini berbentuk deskriptif komparatif sebab data yang diperoleh bersifat apa adanya melaui observasi, dokumentasi, dan wawncara. Kemudian membandingkan dari siklus I siklus II siklus III. Sumber data yang dikumpulkan dalam peneitian ini sebagai berikut:

a. Prilaku siswa dalam kegiatan pembelajaran, yang penilainnya dilakukan oleh guru.

b. Situasi kelas saat kegiatan tindakan pembelajaran, yang penilainnya dilakukan oleh guru.

c. Hasil belajar siswa sebagai dampak aktivitas pembelajaran selama mengerjakan soal essay dari awal sampai akhir.

d. Prilaku guru selama proses pembelajaran berlangsung.

Data yang diperoleh selanjutnya dianalisa menggunakan analisis data kualitatif milik miles dan huberman yaitu dengan reduksi data, penyajian data dan penarikan kesimpulan.

\section{Pembahasan}

1. Siklus I

Berdasarkan pengamatan yang dilakukan selama proses pembelajaran berlangsung diperoleh hasil sebagai berikut:

a. Peserta didik sebagian besar menyukai metode diskusi dan sebagian yang lainnya belum menyukai metode diskusi dalam proses kegiatan pembelajaran.

b. Sebagian siswa masih memiliki sifat malu untuk menyampaikan pendapat dan bertanya.

c. Hasil evaluasi mengenai peningkatan minat belajar siswa masih sedikit yang meningkat.

Berdasarkan pelaksanaan pada siklus 1 diperoleh pelaksanaan pembelajaran masih kurang efektif karena masih belum melakukan kegiatan pembelajaran sesuai dengan RPP, selain itu siswa masih malu untuk mengajukan pertanyaan dan mengemukakan pendapatnya. Untuk mengetahui lebih jautrukh terkait faktor ketidak aktifan siswa, peneliti melakukan wawancara tidak terstruktur dengan beberapa siswa. 
Hasil wawancara peneliti dengan dua orang siswa kelas VII MTs NW Suralaga terkait dengan penerapan metode diskusi pada mata pelajaran Akidah Akhlak. Mereka mengatakan masih kaku dalam mengajukan pertanyaan dan menyampaikan pendapatnya. Di antara alasannya adalah karena belum bisa beradaptasi dengan menggunakan metode diskusi. Selain itu juga, mereka sudah terbiasa dengan metode ceramah yang diterapkan oleh guru Akidah Akhlak pada umumnya. Salah satu dampak dari metode ini adalah selain karena kepuasan dengan apa yang disampaikan oleh guru, mereka juga sudah bosan dan jenuh dengan materinya. Adapun kalau misalnya mereka ingin bertanya kepada gurunya ketika diberikan kesempatan, gurunya tidak memberikan kebebasan kepada peserta didik untuk berkreasi dalam menjawab

2. Siklus II

Berdasarkan pengamatan yang dilakukan selama proses pembelajaran berlangsung diperoleh hasil sebagai berikut:

a. Siswa sudah mulai aktif dalam mengikuti kegiatan pembelajaran.

b. Hasil evaluasi mengenai peningkatan minat belajar siswa sudah mulai meningkat.

Adapun keberhasilan yang diperoleh pada siklus II adalah sebagai berikut:

1) Peneliti sudah mulai bisa membangun minat dan keaktifan belajar siswa dalam pembelajaran Akidah Akhlak.

2) Peningkatan minat belajar siswa sudah mulai kelihatan. Berdasarkan pengamatan peneliti selama proses kegiatan pembelajaran pada mata pelajaran Akidah Akhlak berlangsung pada siklus 1, pembelajaran dengan menggunakan metode diskusi sudah berjalan sesuai dengan prosedur yang telah direncanakan. Namun, sebgaian siswa masih kurang berpartisipasi dalam mengikuti kegiatan pembelajaran dengan serius. Selain itu, siswa masih merasa enggan dan malu untuk mengajukan pertanyaan dan mengemukakan pendapat sendiri sehubungan dengan materi yang didiskusikan. Pertanyaan dan mengemukakan pendapat hanya diajukan oleh sebagian kecil siswa pada siklus pertama berlangsung. Siklus ini, dipake sampai tiga kali pertemuan. 
Berdasarkan hasil wawancara peneliti dengan tiga orang siswa kelas VII MTs NW Suralaga, mereka mengatakan bahwa mereka sudah mulai bisa beradaptasi dengan menggunakan metode diskusi. Karena menurut mereka dengan menggunakan metode diskusi ini, ada tantangan dalam mengikuti proses kegiatan pembelajaran pada mata pelajaran Akidah Akhlak dan mereka sudah mulai aktif untuk menyampaikan pendapat dan mengajukan pertanyaan kepada teman-teman mereka yang lainnya, sehingga suasana kelas terlihat lebih aktif dibandingkan dengan minggu sebelumnya yang masih menggunakan metode ceramah.

3. Siklus III

Berdasarkan pengamatan yang dilakukan selama proses pembelajaran berlangsung diperoleh hasil sebagai berikut:

a. Siswa sudah aktif dan tidak malu-malu lagi untuk bertanya.

b. Dari 18 orang siswa sudah aktif dalam mengikuti proses pembelajaran dengan menerapkan metode diskusi.

c. Siswa sudah berani mengemukakan pendapat sendiri.

Ketika dilakukan evaluasi peningkatan minat belajar siswa pada pembelajaran Akidah Akhlak mengalami peningkatan yang baik.

Adapun keberhasilan yang diperoleh pada siklus III adalah sebagai berikut:

1) Aktivitas peserta didik dalam proses pembelajaran Akidah Akhlak melalui penerapan metode diskusi menarik perhatian siswa hal ini disebabkan peneliti menggabungkan instrumen penelitian soal essay dan tanya jawab sehingga siswa berminat untuk mengikuti proses pembelajaran.

2) Penineliti mampu membangun minat dan keaktifan belajar siswa dalam pembelajaran Akidah Akhlak.

3) Peningkatan minat belajar siswa baik dengan proses pembelajaran yang sesuai dengan RPP yang telah dirancang peneliti.

Berdasarkan hasil wawancara peneliti dengan lima orang siswa kelas VII MTs NW Suralaga mereka mangatakan bahwa merasa senang mengikuti proses kegiatan pembelajaran dengan menggunakan metode diskusi tersebut, karena menurut mereka ada manfaat secara langsung yaitu berani menyampaikan pendapat baik di 
dalam kelompok diskusi maupun sebagai perwakilan dari kelompok menyampaikan hasil diskusi kelompok di depan kelas. Selain itu, mereka juga dapat memperoleh pemahaman yang lebih kuat terkait materi diskusi yang dibagikan oleh guru.

\section{Kesimpulan}

Dilihat dari hasil penelitian tentang meningkatkan minat belajar siswa dengan menggunakan metode diskusi pada mata pelajaran Akidah Akhlak kelas VII MTs NW Suralaga dapat disimpulkan bahwa hasil penelitian ini menunjukkan adanya peningkatan minat belajar Akidah Akhlak dari pada siklus I hasil evaluasi mengenai peningkatan minat belajar siswa masih sedikit yang meningkat, siklus II Hasil evaluasi mengenai peningkatan minat belajar siswa sudah mulai meningkat dan siklus III siswa sudah aktif dan tidak malu-malu lagi untuk bertanya. Untuk mengetahui minat siswa melalui metode diskusi digunakan indikator minat belajar siswa sebagai pedoman guru antara lain Senang terhadap mata pelajaran Akidah Akhlak, memperhatikan apa yang disampaikan guru, aktif dalam kegiatan pembelajaran Akidah Akhlak dan Ketertarikan terhadap mata pelajaran Akidah Akhlak. Terjadinya perubahan dari siklus I, II dan III menujukan bahwa menggunakan metode diskusi sudah efektif dilakukan.

Sebagai tindak lanjut dari penelitian ini peneliti menawarkan beberapa saran:

a. Kepala sekolah sebaiknya selalu memantau kegiatan pembelajaran melalaui supervisi tiap-tiap kelas.

b. Guru hendaknya cermat dalam menggunakan metode pembelajaran yang mampu menarik antusiasme siswa untuk belajar.

c. Bagi peneliti lainnya hendaknya melakukan penelitian sejenis dengan obyek dan subyek yang berbeda untuk memperkaya khasanah ilmu pengetahuan

\section{Daftar Refrensi}

Abu Ahmadi. Metode Khusus Pendidikan Agama Islam. (Jakarta: PT. Bima Aksara, 2009).

Dimyati dan Mudjiono. Belajar dan Pembelajaran. (Jakarta: Rineka Cipta, 2009).

Muhaimin, dkk. Strategi Belajar Mengajar. (Surabaya: CV. Citra Media, 2006).

M. Dalyono, Psikologi Pendidikan. (Jakarta: Renika Cipta, 1997). 
Jasa Ungguh Muliawan, 45 Model Pembelajaran Spektakuler. (Cet. I Ar Ruzz Media, 2016). 